\title{
都市防火対策の系譜と市街地火災時の風の影響 Brief History of Urban Fire Prevention and Wind Effects on the Fires Behavior
}

\author{
竹谷修一 $* 1$ 林 吉彦*2樋本圭佑*3 岩見達也 ${ }^{* 4}$ \\ Shuichi TAKEYA， Yoshihiko HAYASHI， Keisuke HIMOTO， Tatsuya IWAMI
}

1.日本の都市防火対策

1. 1 阪神・淡路大震災以前 1$)$

日本の家屋は木造が多くを占めることから, 古くから 火災による被害を多く受けてきた。火災から家屋を守る ために, 江戸時代には瓦屋根, 土蔵の普及といった建物単 体を燃えにくくする対策が進められるとともに，火よけ 地, 広小路の確保といった都市・地区レベルでの対策が進 められた。さらに, 火消し制度の導入といった消火能力を 向上させる対策も行われてきた。

明治に入ってからも火災による大きな被害が発生して いる。明治 5 年に発生したいわゆる銀座大火では約 95ha が焼失した後, 銀座では煉瓦造りの不燃建築物が建設さ れた (いわゆる銀座煉瓦街の建設)。

地方都市でもたびたび火災が発生している。函館市で は明治以降，火災被害が頻発していたが，明治 11 年及び 明治 12 年の火災後, 基坂, 二十間坂等を防火線として拡 幅整備するともに, 煉瓦造り・石造りによる建築物の不燃 化を推進した。さらに大正 10 年の火災後は, 函館市内の 銀座通りを拡幅し, 沿道建物を RC 造建築物で不燃化し た (写真 1$)$ 。

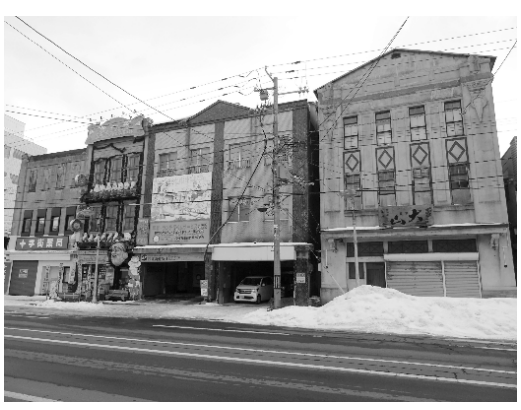

写真 1 銀座通り（函館市）の沿道建物

大正 12 年に発生した関東大震災では甚大な被害が発生 し, 東京市における被害世帯数約 35 万のうち, 全焼した 世帯数は約 30 万であり, 約 $85 \%$ が火災による被害であ った（図 1）2）。また，この地震火災においては火災旋風 が発生し, 被害を拡大させている。本所区の被服廠跡の面 積は $10.3 \mathrm{ha}$ であり, 約 4 万人の避難者とともに大量の家 財道具が持ち込まれている状況であった。夕刻から火災 が三方向から迫るとともに, 火災旋風が発生し, 避難者が 安全な場所一移動することが出来なかったことから, 多 くの避難者が焼死することとなった ${ }^{3) 。 ~}$

\footnotetext{
* 1 国土交通省国土技術政策総合研究所都市研究部都市防災研究室 室長 Head, Urban Disaster Mitigation Div., Urban Planning Dept., National Institute for Land and Infrastructure Management * 2 国土交通省国土技術政策総合研究所建築研究部防火基準研究室 室長 Head, Fire Standards Div., Building Dept., National Institute for Land and Infrastructure Management * 3 国土交通省国土技術政策総合研究所建築研究部防火基準研究室 主任研究官 Senior Researcher, Fire Standards Div., Building Dept., National Institute for Land and Infrastructure Management * 4 国立研究開発法人建築研究所住宅・都市研究グループ 主任研究員 Senior Research Engineer, Dept. of Housing and Urban Planning, Building Research Institute
} 


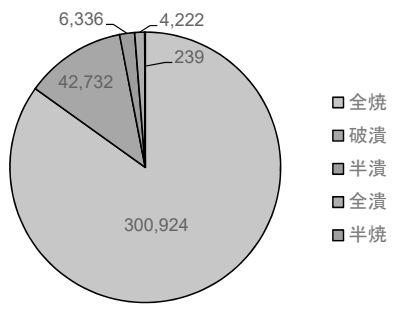

図 1 関東大震災時における東京市の被害別世帯数 (内務省「大正震災誌 上」をもとに作成)

震災後は, 帝都復興院による大規模な震災復興計画が 進められ, その後, 第二次大戦中は防空都市計画による緑 地の整備, 建物疎開というように, 国防という観点から火 災対策が進められた。

戦後に入ると, 土地区画整理事業を中心とする戦災復 興事業等を経て, 建築基準法 (昭和 25 年), 防火建築帯 の造成を図る耐火建築促進法 (昭和 27 年), 街区単位で 防火区画の造成を図る防災建築街区造成法（昭和 36 年） 等が制定されていった。その後, 新都市計画法 (昭和 43 年), 都市再開発法 (昭和 44 年) が制定され, 現在の都市 計画関連の体系が固まった。

一方で, 自治体消防制度が戦後に発足 (昭和 23 年) し, 消防能力が飛躍的に向上していくこととなる。図 2 は, 自治体消防における消防職員数の推移と, 戦後の大火時 の焼損面積を年ごとに合計したものを重ねて示したもの である。

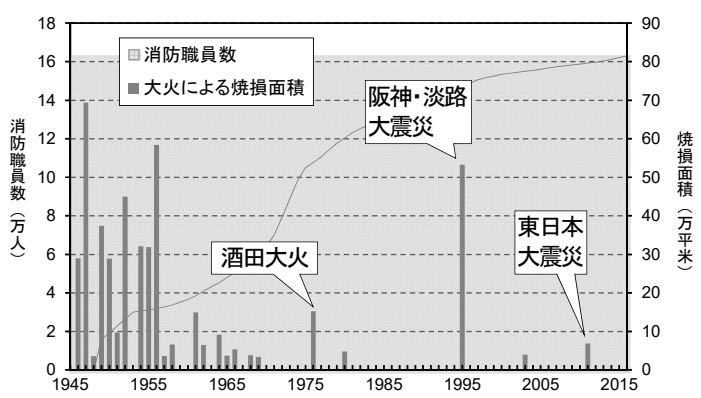

図 2 消防職員数と大火による焼損面積の推移

(「消防白書」をもとに作成)

建物や都市の防火上の対策が進められる中, 消防能力 も徐々に向上していくことにより, 平常時の大火は減少 していった。平常時の市街地大火としては, 酒田大火 (昭 和 51 年。建物の焼損面積は約 15 万 $\mathrm{m}^{2}$ ) を最後に, その 後市街地での大火は平常においては発生しなくなった。

都市として火災を防ぐという観点では，上述したよう に, 建物の不燃化, 道路拡幅, 空地の確保といった対策が
とられてきた。こうした中，建設省（当時）では昭和 52 ～56 年に実施した研究（都市防火対策手法の開発）にお いて, 不燃建築や空地の割合から求める不燃領域率を提 案するとともに, 広幅員の道路, 鉄道, 河川, 大規模な空 地, 而火建築物群等から構成される延焼遮断帯によって 都市を分割 (都市防火区画) し，延燒被害を局限化する手 法を提案している4)。

延焼遮断帯によって形成された都市防火区画内におい て火災が発生しても, 隣接寸る都市防火区画一の延焼を 防ぐ効果が期待される (図 3, 図4)。しかしながら, 都市 防火区画内での延焼を防ぐことまでは出来ない。

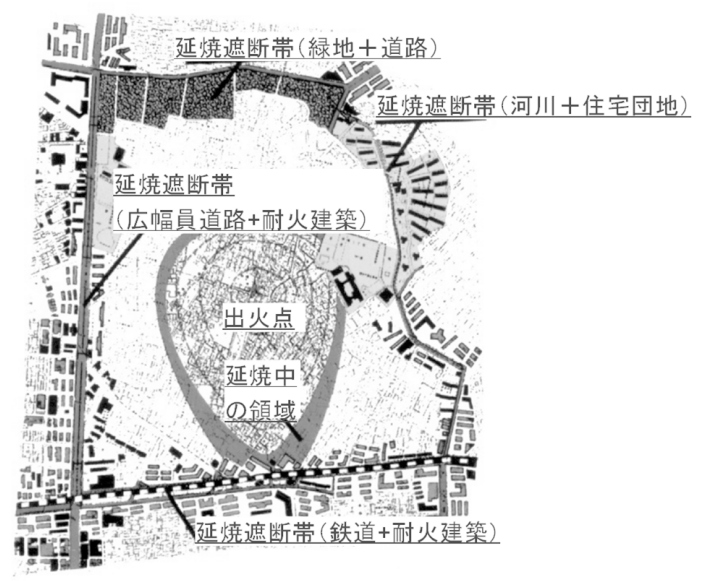

図 3 都市防火区画と延焼遮断帯の例 ${ }^{4}$

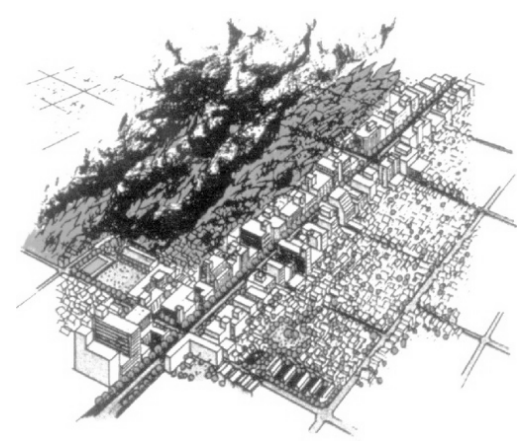

図 4 延焼遮断帯による延焼防止イメージ4)

\section{2 阪神・淡路大震災以降}

平成 7 年に発生した阪神・淡路大震災では, 多数の人 的被害, 建物被害が発生したため, 被災地における復興を 支援するために様々な法律が制定され，迅速な復興を目 指すこととなった。

建物倒壊による被害に比べれば相対的に火災被害は少 なかったものの, 神戸市長田区で 2,500 棟弱が火災被害を 受けたほか, 他の市区でも火災被害が発生した。火災が拡 大していく中で広幅員道路等により火災は焼け止まり, 
延焼遮断機能が発揮されたことが確認されたものの，密 集市街地を中心に大きな火災被害が生じたこともまた事 実である。

この状況を踏まえ, 密集市街地での防火対策をより積 極的に推進するために, 平成 9 年には「密集市街地にお ける防災街区の整備の促進に関する法律 (密集法)」が制 定された。さらに平成 15 年の改正により「特定防災街区 整備促進地区」の制度が創設されるなど, 密集市街地にお ける防災まちづくりが従来以上に推進されることとなっ た。

一方，都市再生本部の第三次決定（平成 13 年 12 月） では「地震時に大きな被害が想定される危険な密集市街 地について, 特に大火の可能性が高い危険な市街地を対 象に重点整備し, 今後 10 年間で最低限の安全性を確保す る。」ことを決定した。これを受けて国土交通省では，平 成 15 年 7 月に「地震時等において大規模な火災の可能性 があり重点的に改善すべき密集市街地」である全国約 8,000ha の地区について公表し, 地方公共団体による密集 市街地整備の支援を進めていった。

その後, 平成 23〜32 年度の 10 年間を計画期間とする 新たな「住生活基本計画 (全国計画)」が閣議決定された

(平成 23 年 3 月 15 日)。この新たな住生活基本計画にお いては, 住生活の安全を確保する住宅及び居住環境の整 備の成果指標の一つとして, 「地震時等に著しく危険な密 集市街地の面積」が新たに位置づけられている。

密集市街地解消のための基本的な施策として, 延焼・倒 壊の危険性の高い老朽建築物の建替え・除却, 道路幅員等 に関する建築基準法上の緩和措置の活用等により密集市 街地の整備の促進等が位置づけられている。あわせて, 密 集市街地解消の目標として, 平成 22 年に約 $6,000 \mathrm{ha}$ 存在 する密集市街地を，10 年後には概ね解消することとして いる。

\section{2. 平成 28 年に発生した糸魚川市での火災 ${ }^{5)}$}

平成 28 年 12 月 22 日に新潟県糸魚川市で発生した火災 では，焼損棟数 144 棟，焼損区域面積約 $40,000 \mathrm{~m}^{2}$ に及ぶ 被害のとなり, 地震火災以外では比較的規模が大きな火災 となった。国土技術政策総合研究所及び建築研究所は, こ の火災による建物の被害について, 延焼拡大及び焼け止 まり要因等を検討するために現地調査を実施した。以下， 調査結果の概要を示す。

2. 1 気象状況

気象庁のアメダス観測所 (系魚川)によれば, 火災当日 の風向と風速は図 5 のように, 風向はほぼ南, 火災覚知
（消防署が火災の発生を認知すること）から19 時までの 間, 風速は $10 \mathrm{~m} / \mathrm{s}$ 前後 (10 分間平均值), 最大瞬間風速は $20 \mathrm{~m} / \mathrm{s}$ 前後で推移している。また, 12 時 10 分には最大瞬 間風速が $24.2 \mathrm{~m} / \mathrm{s}$ (風向は南) を記録しており, 強風下で の火災であったといえる。

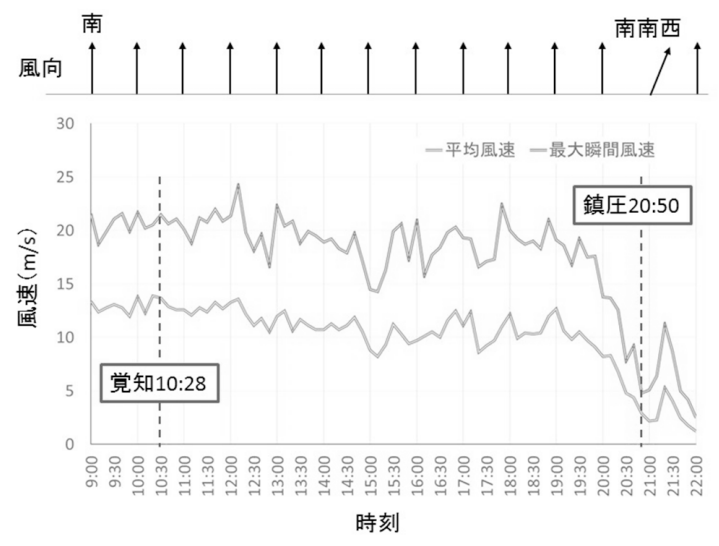

図 5 アメダス観測地点（糸魚川）における 火災当日の風速と風向

\section{2 地区の状況}

糸魚川市は昭和 35 年に今回の焼損区域を含む $26.89 \mathrm{ha}$ を準防火地域に指定し, さらに昭和 43 年には東側の近隣 商業地域を追加指定して現在では $32.2 \mathrm{ha}$ となっている。

過去には明治 44 年, 昭和 3 年及び 7 年にそれぞれ大規 模な火災が発生しているが，このうち，昭和 7 年に発生 した火災では，今回の焼損区域を含む広範な地区におい て延焼しており, その後復興に際して, 道路の拡幅が行わ れている。

また, 火災発生時点では, 写真等から判断する限り古い 建物が多く, 準防火地域の建物に求められる外壁や空な どの開口部に防火上の対応がなされていない建物が混在 していたと考えられる。

\section{3 火災被害の様子}

焼損区域の範囲と調査対象建物の位置を示したものが 図 6 である。なお，焼損区域は，調査時点での糸魚川市 公表資料 のに示された大火被災エリアを基に記載してい る。焼損区域は南北方向に最大で約 $300 \mathrm{~m}$, 東西方向に最 大で約 $200 \mathrm{~m}$ となっている。焼損区域の南端近くで発生 した火災は強い南風にあおられながら, 海沿いの国道 8 号まで延焼している。

火元建物近くの, 延焼した仲道線沿道建物の外壁は残 っている (写真 2$)$ 。かしながら, 背後は燃え落ち, さ らに背後の建物一延燒拡大している(写真.3)。 


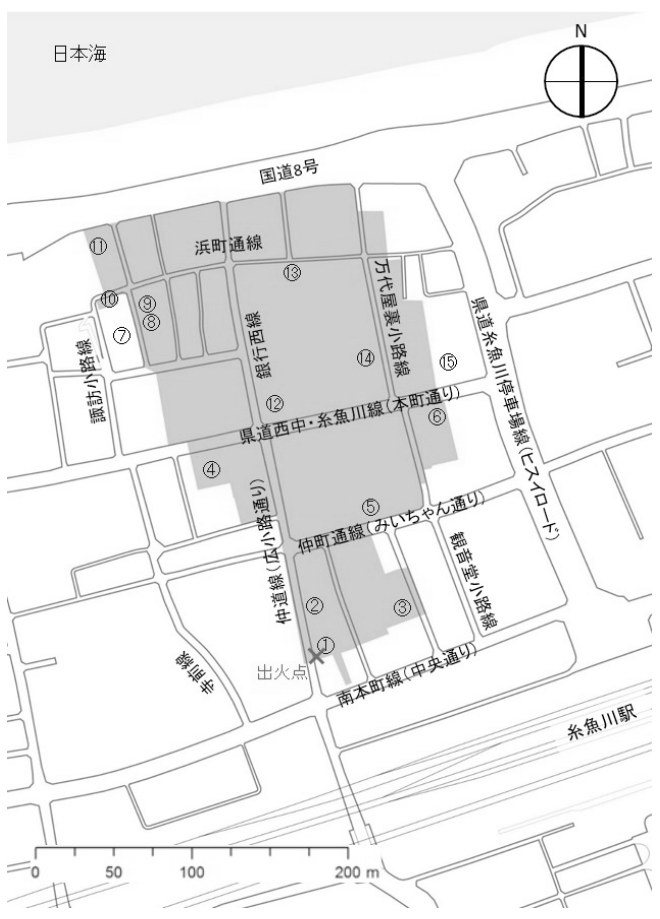

図 6 焼損区域の範囲と調査対象建物（11～(15)

(国土地理院基盤地図情報に焼損区域等を加筆)

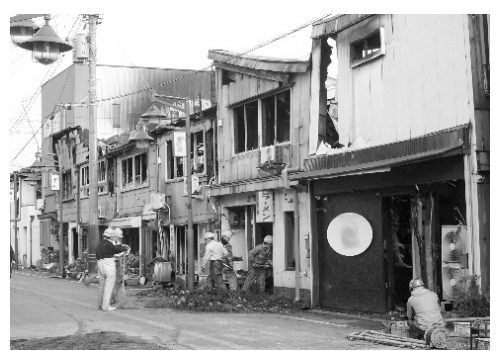

写真 2 火元建物付近の様子

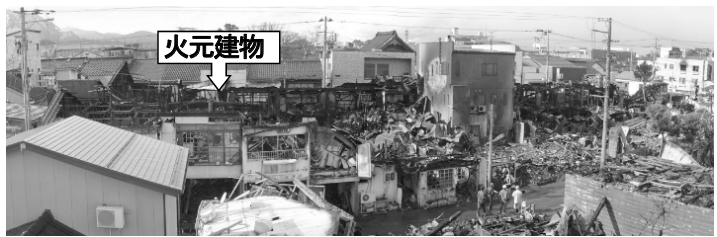

写真 3 火元建物背面の様子

焼損区域中央にあたる県道西中・糸魚川線付近では, 仲 道線西側の街区へ延焼が及ぶとともに（写真 4), 東側一 の延焼が拡大している（写真 5)。また, 県道西中・糸魚 川線（道路台帳では $10 \mathrm{~m}$ 程度の幅員）北側の街区へも延 焼が拡大している (写真6)。

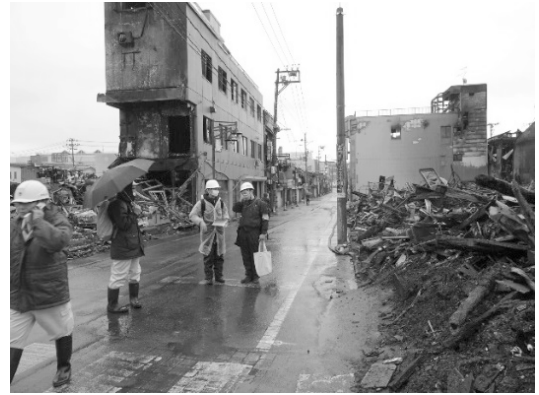

写真 4 火元建物より北側の仲道線の様子

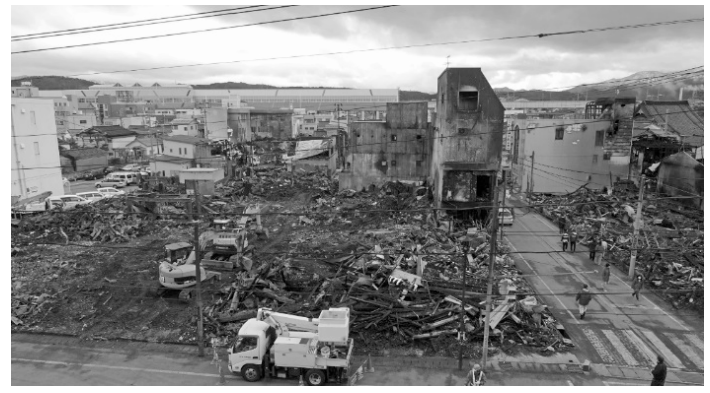

写真 5 県道西中・糸魚川線以南の焼損状況 (写真右側は仲道線)

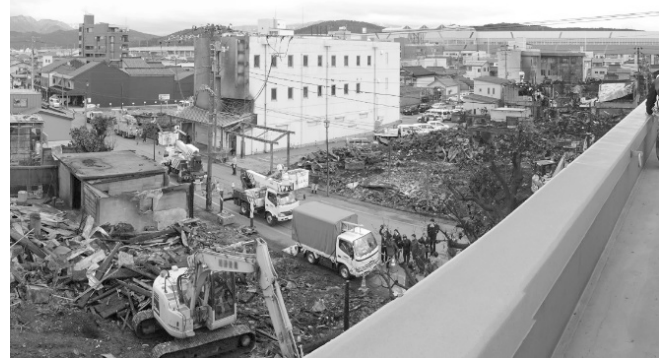

写真 6 県道西中・糸魚川線の北側及び南側の焼損状況 (写真左前が北側)

また, 焼損区域中央の図6中の12番の建物の屋上では, シート防水層に穴が開いた箇所が多数残されており，多 数の火の粉が飛散してきたものと考えられる（写真 7)。

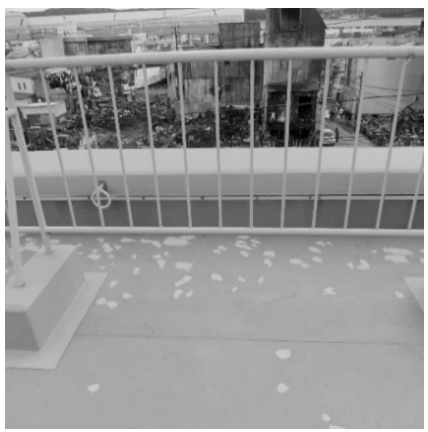

写真 7 屋上パラペット付近の様子 
焼損区域北部にあたる，海沿いの国道 8 号より 1 本南 側に位置する浜町通線の沿道では，多くの建物が焼損寸 るなか，焼失を免れた住宅（図 6 中の11番の建物）が 1 棟あり（写真 8), その北側及び東側には駐車場があり, 南側は植栽のある庭となっていた。

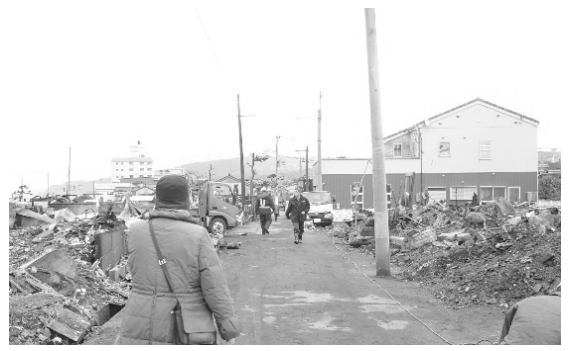

写真 8 焼失を免れた住宅

\section{4 飛び火の状況}

飛び火は火の粉が飛散・落下して出火する現象》である。 焼損区域の中には, 住民一の聞き取り, 報道機関等により 撮影された映像の解析, 火災現場の焼損状況等から, 飛び 火による延焼の可能性がある箇所が多数確認されている。 隣接する周囲の建物が燃焼していないが，建物等から煙 や火炎の噴出を確認できたものを飛び火による延焼と見 なしてその範囲を示したものを図 7 に示す。

延焼状況を推定するに足りる情報が得られていないが, 飛び火があった可能性を否定できない範囲を，図中に灰 色で示している。今後, 追加ヒアリングや映像情報の分析 により, 飛び火の発生場所について精査予定である。

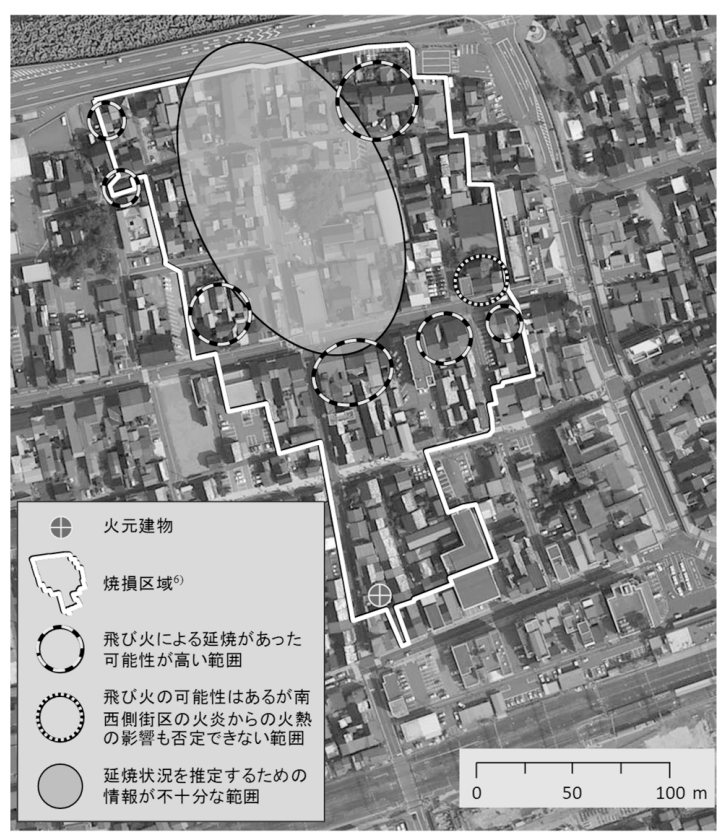

図7 飛び火による延焼の分布

写真出典 : 国土地理院撮影の空中写真（2009 年撮影）
3. 市街地火災の延焼速度

図 8 は, 川越 ${ }^{8)}$ による戦前から 1949 年 (昭和 24 年)ま での市街地火災に関する風速と延焼速度の関係を表す図 に筆者がいくつかのデータを追加したものである。

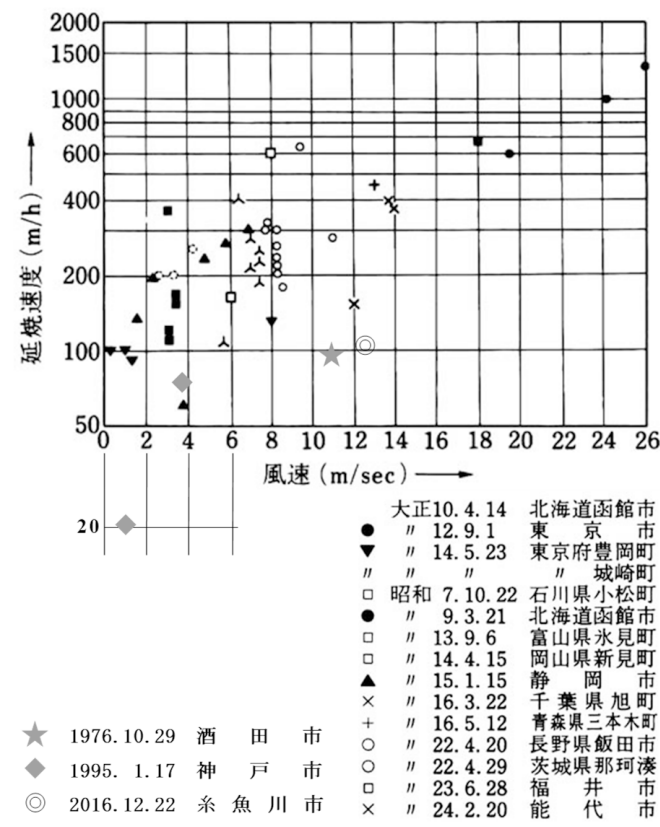

図 8 市街地火災に関寸る風速と延焼速度の関係 (参考文献 8 に加筆)

まず 1949 年までのデータに関して見てみると, 無風時 には $100 \mathrm{~m} / \mathrm{h}$ 程度の延焼速度であるが，風速 $20 \mathrm{~m} / \mathrm{s}$ では $1,000 \mathrm{~m} / \mathrm{h}$ 程度となっており, 風速が増すほど指数的に延 焼速度が増加することが示されている。同じ図上に比較 的最近の大火である 1976 年酒田大火および 1995 年兵庫 県南部地震時のデータ及び前章で述べた2016年に発生し た糸魚川市における大規模火災のデータを追加した。

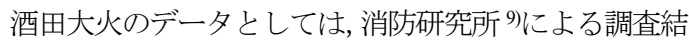
果から，延焼速度は $90 \mathrm{~m} / \mathrm{h}$ ，風速に関しては酒田測候所 による平均風速 $11.0 \mathrm{~m} / \mathrm{s}$ を採用した。兵庫県南部地震に 関しては, 風速 $1.0 \mathrm{~m} / \mathrm{s}$ で延焼速度 $20 \mathrm{~m} / \mathrm{h}$, 風速 $3.9 \mathrm{~m} / \mathrm{s}$ で 延焼速度 $73 \mathrm{~m} / \mathrm{h}$ の 2 点 ${ }^{10)}$ をプロットした。2016 年 12 月 に新潟県系魚川市で発生した市街地火災では, 出火から 約 2 時間 40 分後の 13:00 ごろに約 $280 \mathrm{~m}$ 風下の海岸沿い

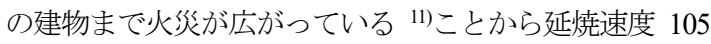
$\mathrm{m} / \mathrm{h}$, 平均風速は最寄りのアメダス観測所（系魚川）によ る出火後 3 時間の平均風速 $12.5 \mathrm{~m} / \mathrm{s}$ とした。

1949 年以前と比較すると 1976 年以降では遅い值が観 測されていることがわかる。酒田大火では平均 $1 \mathrm{~mm} / \mathrm{h}$ 程 度の降雨があったこともいくらかの影響はあったと思わ れるが, 準防火地域に指定され, 防火構造又は耐火構造の 
建築物が混在した市街地 ${ }^{9}$ であったこと, また近年ではさ らに耐火建築物や防火構造の建築物が多くなっているこ とが，1949 年までの裸木造を主体とする市街地の延焼速 度との差に現れていると考えられる。延焼速度は遅くな っているとはいえ, 風速との相関は認められ, さらに強風 時には 1 時間あたり数百メートル程度の延焼速度となる 可能性が示唆される。

\section{4. 飛び火}

風速に応じて延焼速度が増す主な要因の一つとして飛 び火による延焼が挙げられる。特に強風時には延焼速度 を規定する最も大きな支配要因と考えられている。

2016 年の采魚川市における大規模火災においても飛び 火の発生が多数確認されており, 図 8 に示した延焼速度 も飛び火による延焼の結果として観測された值である。

飛び火による延焼過程については未解明な部分も多く 現在も各方面で検討が進められているが，一例として 2012 年に実施された実大火災実験において観測された火 の粉の飛散性状について紹介する ${ }^{12 \sim 14) 。 ~}$

\section{1 火の粉の発生性状}

詳細は参考文献 ${ }^{13)}$ に諒るが，火の粉の観測を行った木 三学 (木造三階建て学校) 予備実験の概要を以下に示寸。

i) 実施日時: 2012 年 2 月 22 日 午前 9:00 点火

ii) 実施場所: 国土技術政策総合研究所敷地内(つくば市)

iii) 建物概要: 木造, 3 階建て, 1 時間準耐火構造（屋

根・階段は 30 分), 2,265 $\mathrm{m}^{2}$ (推定木材使用量: $675 \mathrm{~m}^{3}$,

$256,500 \mathrm{~kg}$ )

iv) 風向・風速: 東北東加東の風, 平均 $4.9 \mathrm{~m} / \mathrm{s}$ （地上

$10 \mathrm{~m} ， 9: 00 \sim 11: 00$ ）（図 9）

v) 主な火災性状：1 階に点火した後, 6 分 20 秒までに

2 階及び 3 階室内に着火, 30 分過ぎに屋根の燃え抜け が発生, 65 分頃には炎上のピークを越え, 76 分〜 123 分にかけて倒壊が進んだ。

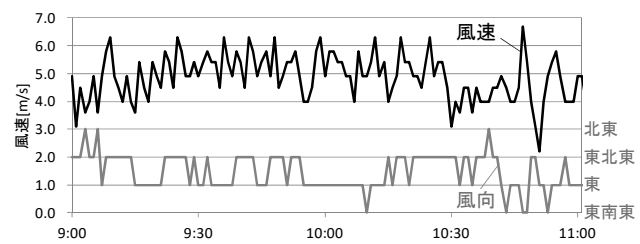

図 9 風向・風速

4. 2 火の粉の収集 ${ }^{14)}$

4. 1 に示したとおり, 燃焼は極めて早く進行し，3 層 同時に炎上する状況が確認された。点火から 18 分頃から 火の粉の降積が観察されはじめ, 屋根の然え抜け以降, 数, 大きさともに火の粉の増加が確認された。火の粉は
2012 年 2 月 22 日から 3 月 31 日にかけて田畑の区画ごと に収集した（図 10, 写真9)。

表 1 は木三学予備実験で収集した火の粉について, 田 畑の区画ごとに降積密度を示している。

以下では，卓越風向である東から西向きを $\mathrm{X}$ 軸，直交 方向に南から北向きを $\mathrm{Y}$ 軸とする。

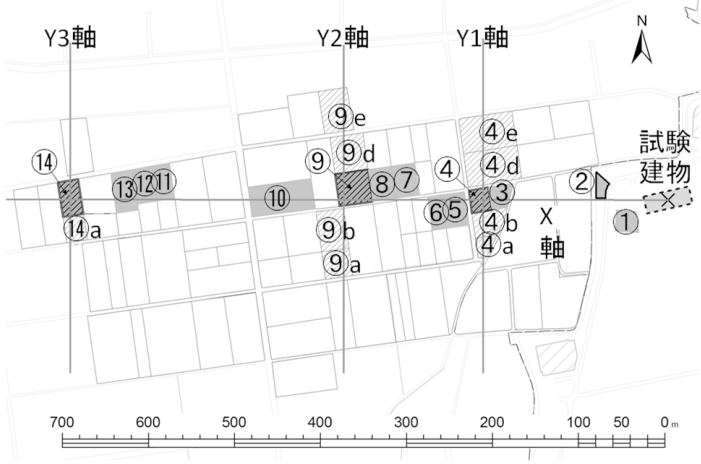

図 10 火の粉の収集を行った田畑

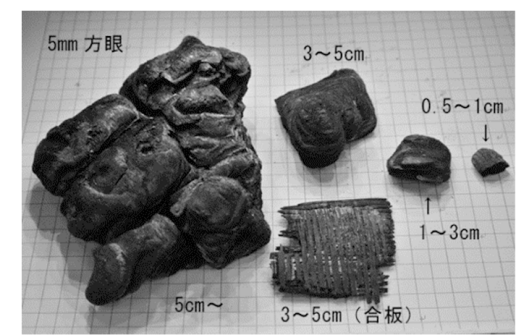

写真9 収集した火の粉（218m 地点）

表 1 区画ごとの火の粉降積密度

(a)X 軸方向

\begin{tabular}{|c|c|c|c|}
\hline $\begin{array}{c}\text { 区画 } \\
\text { 名称 }\end{array}$ & $\begin{array}{c}\text { 計測 } \\
\text { 軸 }\end{array}$ & $\begin{array}{c}\text { 距離 } \\
(\mathrm{m})\end{array}$ & $\begin{array}{c}\text { 降積密度 } \\
\left(\mathrm{g} / \mathrm{m}^{2}\right)\end{array}$ \\
\hline (1) & $\mathrm{X}$ 軸 & 54 & 10.7 \\
\hline (2) & $\mathrm{X}$ 軸 & 79 & 8.96 \\
\hline (3) & $\mathrm{X}$ 軸 & 195 & 2.3 \\
\hline (4) & $\mathrm{X}$ 軸 & 218 & 1.28 \\
\hline (5) & $\mathrm{X}$ 軸 & 248 & 0.65 \\
\hline (6) & $\mathrm{X}$ 軸 & 269 & 0.44 \\
\hline (7) & $\mathrm{X}$ 軸 & 306 & 0.77 \\
\hline (8) & $\mathrm{X}$ 軸 & 333 & 0.57 \\
\hline (9) & $\mathrm{X}$ 軸 & 366 & 0.18 \\
\hline (10) & $\mathrm{X}$ 軸 & 449 & 0.16 \\
\hline (11) & $\mathrm{X}$ 軸 & 587 & 0.09 \\
\hline (12) & $\mathrm{X}$ 軸 & 608 & 0.06 \\
\hline (13) & X軸 & 632 & 0.06 \\
\hline (14) & X軸 & 694 & 0.01 \\
\hline
\end{tabular}

(b) Y 軸方向

4. 3 火の粉飛散モデル

風向と平行方向は対数正規分布 (式 1) を, 風向と直交 方向は正規分布（式2）をそれぞれ仮定すると, 表 1 のデ ータもこの仮定にほぼ従った分布となっている。

$w_{u, x}=\frac{1}{\sqrt{2 \pi} \sigma_{X} x} \exp \left[-\frac{\{\ln x-\bar{\mu}+\ln (\bar{u} / u)\}^{2}}{2 \sigma_{X}^{2}}\right] \times W_{g}$ 


$$
w_{u, x y}=\frac{1}{\sqrt{2 \pi} \sigma_{Y}} \exp \left\{-\frac{(y / x)^{2}}{2 \sigma_{Y}^{2}}\right\} \times \frac{w_{u, x}}{x}
$$

$x, y: \mathrm{X}$ 軸方向及び $\mathrm{Y}$ 軸方向の位置 $[\mathrm{m}]$

$\bar{\mu}:$ 基準風速における分布パラメータ

$\sigma_{X}, \sigma_{Y}:$ 分布パラメータ

$\bar{u}, u:$ 基準風速及び風速 $[\mathrm{m} / \mathrm{s}]$

$W_{g}$ : 火の粉発生量 $[\mathrm{g}]$

$w_{u, x}:$ 位置 $x$ における火の粉降積密度 $[\mathrm{g} / \mathrm{m}]$

$w_{u, x y}$ : 位置 $x, y$ における火の粉降積密度 $\left[\mathrm{g} / \mathrm{m}^{2}\right]$

（1）風向と平行方向の分布パラメータの推定

風向と平行方向は対数正規分布を仮定し，表 1(a)の観 測值を用いて単位放出角 $(y / x=1)$ あたりの降積密度（表 1 の降積密度と距離を乗じた值) に合うように最小二乗法 を用いてパラメータ（ $\bar{\mu}$ 及び $\sigma_{X} ）$ の推定を行った。その 結果, $\bar{\mu}=5.00$ 及び $\sigma_{X}=0.747$ となった。

火の粉の観測を行った際の平均風速は $4.9 \mathrm{~m} / \mathrm{s}$ であり, 上記 $\bar{\mu} は 4.9 \mathrm{~m} / \mathrm{s}$ を基準とした場合のパラメータである。 火の粉の到達距離が風速に比例すると仮定すれば，風 速 $10 \mathrm{~m} / \mathrm{s}$ を基準とすると式 3 の通り， $\bar{\mu}=5.71$ となる。

$$
\bar{\mu}_{(10)}=\bar{\mu}_{(4.9)}-\ln (4.9 / 10)=5.71
$$

\section{(2)風向と直交方向の分布パラメータの推定}

風向と直交方向は平均 0 の正規分布を仮定し，表 1(b) の観測值を用いて(1) と同様に単位放出角 $(y / x=1)$ あたり の降積密度に合うように最小二乗法を用いてパラメータ

$\left(\sigma_{Y}\right)$ の推定を行った。その際, 火の粉密度は位置 $\mathrm{x}$ に応 じて変化するため， $x=100 \mathrm{~m}$ での值に基準化した（すな わち, 観測值に $w_{u, 100} /\left(100 w_{u, x}\right)$ を乗じた $)$ 。その結果, $\sigma_{Y}=$ 0.142 となった。

観測結果とモデルによる曲線を図 11 及び図 12 に示す。

\section{5。灭災旋風}

火災旋風は, 大規模な屋外火災に付随して発生する竜 巻状の渦 (火炎を伴う場合と伴わない場合とがある) で, 発生の条件によっては大きな被害をもたらす可能性があ る現象である。例えば，1923 年関東地震では，当時の東 京市内で約 110 か所, 横浜市内で約 30 力所の火災旋風の 発生が確認されている（中には小規模な渦も含まれてい るものと考えられる)。このうち本所被服廠跡で発生した 巨大な火災旋風により，避難していた 4 万人のうち 3 万

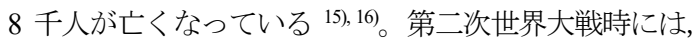
空襲による爆撃を受けた和歌山市でも複数の火災旋風の

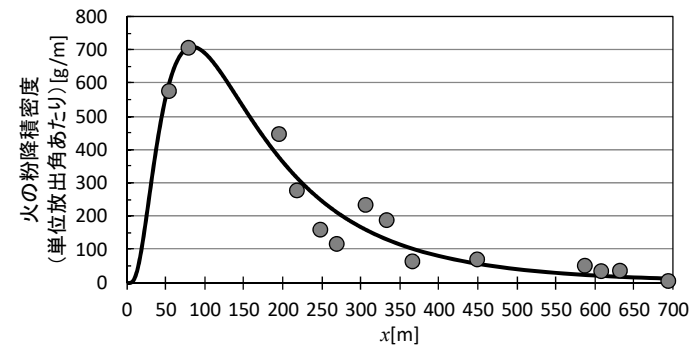

図 11 風向と平行方向の分布

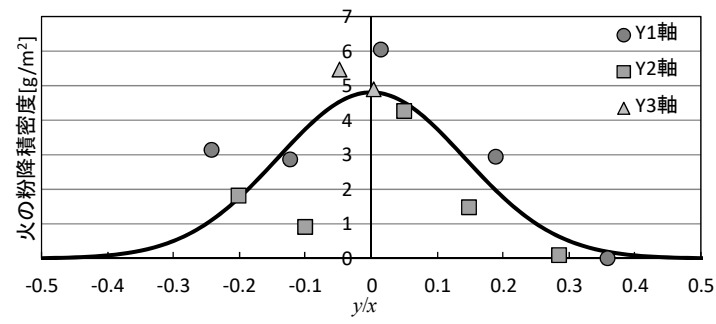

図 12 風向之直交方向の分布

発生が報告されている。このうち旧県庁跡の空地で発生 した火災旋風により, 当夜の空襲による死者の 6 割強に 及ぶ 748 人の死者を出している ${ }^{17)}$ 。近年では, 2011 年東 北地方太平洋沖地震の際に, 気仙沼市の火災現場で火災 旋風の発生が目撃されている。周辺は津波による浸水被 害を受けており，住民も避難をした後であったため大規 模な被害の発生にはつながっていないものの, 少なくと も約 70m の高さの火炎の渦が形成されていたと推定され ている ${ }^{18)}$ 。海外では, 市街地火災というよりも, 森林火 災に付随した火災旋風の発生が頻繁に確認されており, 燃焼領域の拡大防止だけでなく, 消防隊の安全確保の観 点からも関心が高い。なお, 森林火災での火災旋風につい ては撮影された動画がウェブ上に公開されていることが 多いので, 関心のある方は検索をしてみていただきたい。 5. 1 火災旋風の種類

火災旋風と一口に言っても, 実は, 過去に確認された火 災旋風の火源 (規模, 形状) や風などの発生条件はまちま ちである。現象を理解する上では, こうした条件の類型化 が有効であるが, Soma らは火災旋風の代表的な発生条件 を図 13 に示寸 DFW 型, HFW 型, HAFW 型の 3 種類に 分類している ${ }^{19)}$ (ここに含まれない発生条件も確認され ているため, 網羅的ではない)。

このうち DFW 型は, Dessens による屋外実験 $(125 \mathrm{~m} \times$ $125 \mathrm{~m}$ の範囲に設置された最大出力 $700 \mathrm{MW}$ のガスバーナ 一を燃焼させたもの）において確認された火災旋風に由 来しており，風下側に吹き倒された上昇気流の下部に形 成される漏斗状の火災旋風である ${ }^{20}$ 。 。最近の研究による と, 上昇気流が周辺の空気を巻き込む過程で形成される 


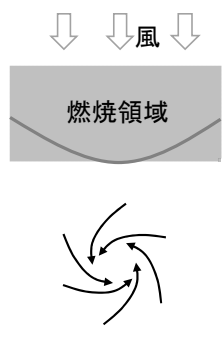

DFW型

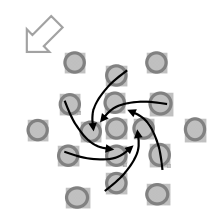

HFW型

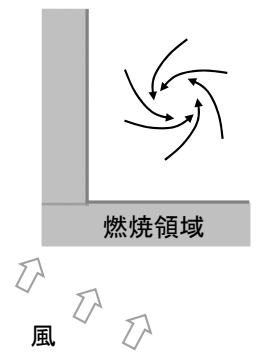

HAFW型
図 13 火災旋風の分類例 ${ }^{19}$

渦対 (互いに逆向きに回転) が, 燃焼領域周辺の高温の気 体を吸い上げることで DFW 型の火㷋旋風が発生してい るとの報告がある ${ }^{21)}$

HFW 型は, 第二次世界大戦中に空襲による爆撃を受け た Hamburg 市で発生した火災旋風に由来しており, 非対 称に分布する多数の火源の上方に形成される火災旋風で ある。空襲時の Hamburg 市周辺の気象条件は静穏であっ たとされることなどから，他の 2 類型とは異なり，風の 有無が発生条件に及ぼす影響は相対的に小さいと考えら れている。なお, Hamburg 市の事例では, 火災旋風の直径 が 2.4〜 3km，高さが $5 \mathrm{~km}$ に及んだとされる 222。

HAFW 型は, 関東地震の際に $10.3 \mathrm{ha}$ ほどの空地（本所 被服廠跡) で発生し，15〜20 分間ほど空地内を移動し続 けて被害を拡大した火災旋風に由来している。当時は, 地 震発生当時の気象条件（関東地方に不連続線が発生して いた）に関連付けて火災旋風の発生が説明されることが 多かったようである。しかし, 火災延焼動態の調查記録に よると, 発生当時の本所被服廠跡周辺には $\mathrm{L}$ 字型の燃焼 領域が形成されていたことが分かっており，現在ではこ こに風が加わることで非対称な流れが生じ，上昇気流の 旋回をもたらしたとする考えが一般的である ${ }^{19) 。 ~}$

\section{2 火災旋風の発生条件}

大規模な火災被害をもたらす市街地火災は強風時に発 生することが多いせいか，火災旋風は強風下で発生しや すい現象と一般には考えられているようである。しかし， 上述した火災旋風の発生事例のうち, 発生箇所周辺の風 速記録が残されているものを見ると，例えば和歌山市の 場合には $2.5 \mathrm{~m} / \mathrm{s}$, 気仙沼市の場合には最大でも $2.8 \mathrm{~m} / \mathrm{s}$ で あったとされ, 強風でない場合であっても火災旋風は発 生している。また, 関東地震の際には, 日本列島周辺を大 型の低気圧が通過中で強い風が吹いていたとされるが, 本所被服廠跡で火災旋風が発生した時間帯の風速は 4〜 $5 \mathrm{~m} / \mathrm{s}$ であったとの指摘もあり ${ }^{17)}$, この場合も強風と言え
るほどの気象条件ではなかった可能性がある。

図 14 は, 発熱速度や流入風速といった条件が火災旋風 発生に及ぼす影響を調べるために行われた風洞実験の様 子を示している23)。また図 15 は, この実験において火災 旋風の発生頻度 $p$ がどのように変化したのかを, 次に示 すフルード数に相当する無次元数 $\Omega$ を用いて整理した結 果である。

$$
\Omega \equiv\left(\frac{\dot{Q}^{\prime} g}{c_{P} \rho_{\infty} T_{\infty} U_{\infty}^{3}}\right)^{1 / 3}
$$

ここで, $Q^{\prime}$ は単位長さあたりの発熱速度, $g$ は重力加速 度, $c_{P}$ は比熱, $\rho_{\infty}$ は外気比重, $T_{\infty}$ は外気温度, $U_{\infty}$ は流 入風速である。

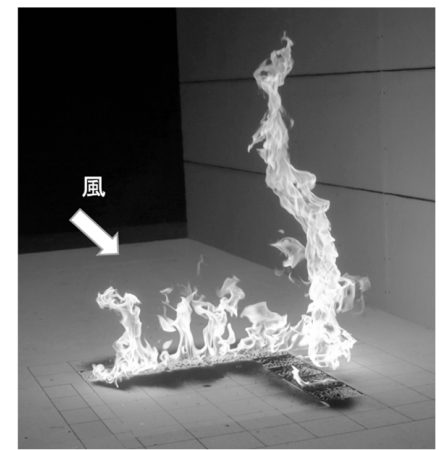

図 14 風洞実験で再現された火災旋風 24)

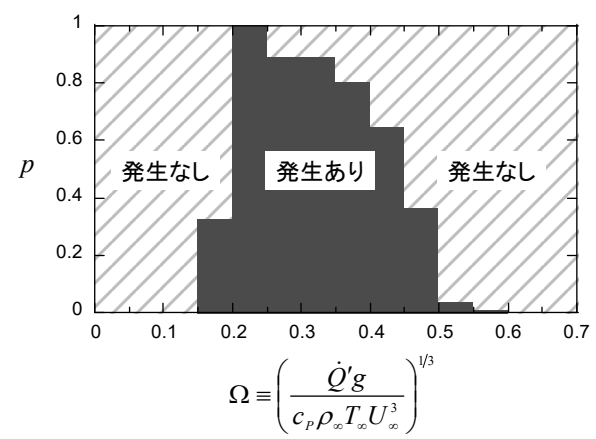

図 15 火災旋風の発生頻度 23 ) 加筆

この実験は L 字型火源（図 14 における HAFW 型に相 当）のみを対象としたものではあるものの, 図 15 では無 次元数 $\Omega$ が一定の範囲内にあるときに火㷋旋風の発生頻 度 $p$ が高くなることが分かる。このことはすなわち, 発 熱速度 $Q^{\prime}$ と流入風速 $U_{\infty}$ のうち，いずれか一方が大きす ぎても，逆に小さすぎても火災旋風は発生しないという こと示している。

なお, 関東地震の際には, L 字型の燃焼領域の外側に火 災旋風が移動したとされるが, 図 14 に示した実験で発生 
した火災旋風は，ほぼ $\mathrm{L}$ 字型の燃焼領域の内側にとどま っていた。関東地震の際の映像記録などを見ると, 住民は 自らの家財道具を大八車に積み上げて避難をしていたよ うであり, 本所被服廠跡においては, このように可燃物が 集積していたことが然焼領域の外側での火災旋風の発生 につながった可能性がある。現代の市街地で大規模な火 災が発生した場合に同じような避難が行われるとは考え にくいが，建物を含む市街地の構造的要因以外にも火源 条件を左右する要因がある点には留意が必要である。

\section{3 火災旋風の内部構造}

火災旋風がどのような加害性を有するのかは，温度や 流速などといった火災旋風の内部構造によって決定され る。ただし，図 14 に示したような風洞実験では火災旋風 が 1 力所に定在せず，内部構造を明らかにすることには 適さないので, スリットを設けた衝立 (もしくはメッシュ 状のスクリーン) を火源の四周に配置し, 火源への空気の 供給を制御することで旋回流が発生しや寸い流れ場を作 るといった方法がとられることがある。

図 16 は, ガスバーナーを用いた場合の中心軸上の温度 上昇 $\Delta T_{0}$ の測定結果を無次元高さ $Z$ （軸上高さ $z$ を平均 火炎高さ $H_{f}$ で正規化したもの) で整理した結果である 24)。連続火炎領域, 間欠火炎領域, 熱気流領域の 3 領域に 分割した場合, 連続火炎領域の温度上昇 $\Delta T_{0}$ が高さ $Z$ に よらずほぼ一定である点など, 乱流拡散火炎と特徵が似 通っている点は多い。ただし, 連続火炎領域の温度上昇 $\Delta T_{0}$ は, 乱流拡散火炎の場合が最大で $850^{\circ} \mathrm{C}$ 程度であるの に対し, 火災旋風の場合には $1000^{\circ} \mathrm{C}$ 程度に達寸ることが 分かっている。 $150^{\circ} \mathrm{C}$ 違いは微妙に感じられるかもしれ ないが，放射体として周囲に放射するエネルギ一の大き さは絶刘温度の 4 乗に比例するので，火災旋風の放射工 ネルギー (黒体を仮定) は, 通常の乱流拡散火炎に比べて 約 1.5 倍の大きさとなる。

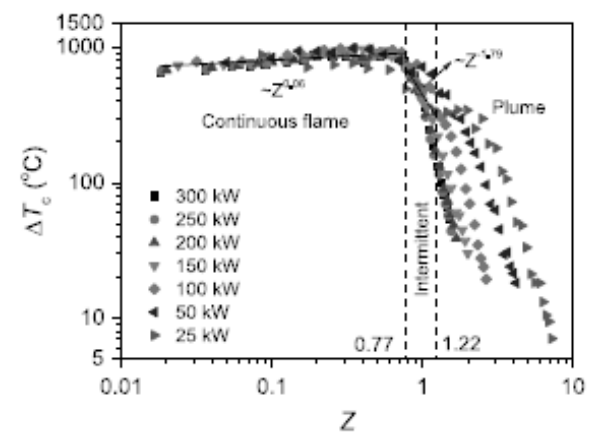

図 16 中心軸上の温度上昇 ${ }^{24)}$

また, 本所被服廠跡で発生した火災旋風では, 引き裂か
れるように切断された樹木の径などから, 最大で $80 \mathrm{~m} / \mathrm{s}$ ほ

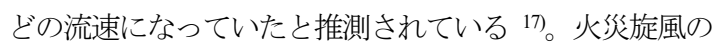
流速 (円筒座標系を適用した場合の周方向成分) はバーガ 一ス渦で近似でき, 連続火炎領域における火災旋風コア の半径は, 火源の発熱速度 $Q$ の $0.2 \sim 0.3$ 乗に比例するこ

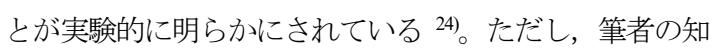
る範囲では, 残念ながら流速の測定結果を一般化する試 みはなされていないようなので, 測定結果から実際の火 災旋風の最大流速を推測することは難しく, 今後の検討 が待たれている。

\section{6. 今後の課題}

系魚川市での焼損区域においては，準防火地域の指定 がされているものの, 必要とする防火的な措置がなされ ない建物も多く混在していたと思われる。従来, 防火上の 対応が十分図られていない市街地においては, 地震時に は市街地火災の発生が危惧されていたところであるが, 平常時であっても, 強風下ではその危険性があることが 改めて示された。

また, 今回, 火の粉による飛び火の発生が改めてクロー ズアップされた。火元から離れた場所で思わ炏災を招 き, 市街地火災の拡大を助長するものである。屋根が一番 の弱点と考えられるが, 飛び火の発生メカニズムは, 実験 等を通じて工学的な検証が必要である（写真 10）。また, 市街地火災では, 強風が収まったときの火災旋風の発生 も懸念される。火災旋風の発生メカニズムについても検 証を継続する必要がある。

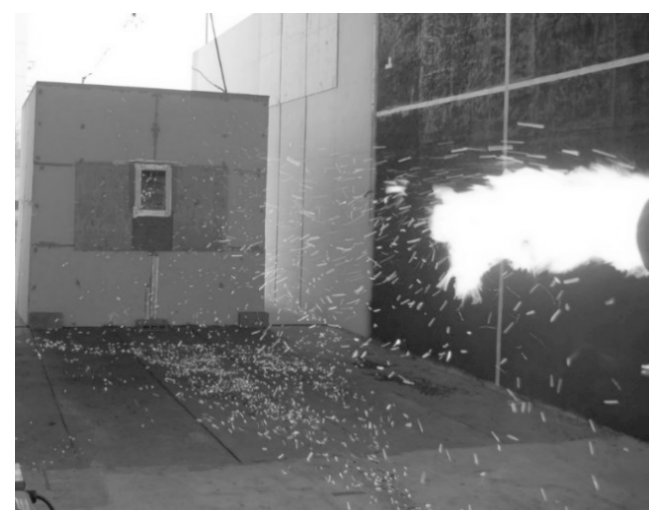

写真 10 実験のイメージ（建築研究所火災風洞実験棟 における火の粉による建物への加害性解明の実験)

\section{謝辞}

糸魚川での火災調查を実施するにあたり, 御協力いた だいた方々, 関係資料を御提供いただいた方々に対し，こ 
こに深謝申し上げます。また, 本火災で被災された方々に 心からお見舞いを申し上げるとともに, 被災地の一刻も 早い復興を祈念いたします。

\section{参考文献}

1）都市防災実務ハンドブック編集委員会，「都市防災実 務ハンドブック＼cjkstart地震防災編」,pp. 124,(1997)

2) 内務省，「大正震災誌上」,(1926)

3) 西田 幸夫, 「関東大震災における避難」, 2012 年度日 本建築学会大会防火部門パネルディスカッション資 料・広域避難計画を再考する, pp. 7 10, (2012)

4) 建設省，「総合技術開発プロジェクト 都市防火対策 手法の開発 報告書」,(1982)

5）国土交通省国土技術政策総合研究所・国立研究開発 法人建築研究所，「平成 28 年（2016 年）12月 22 日 に発生した新潟県系魚川市における大規模火災に係 る現地調查報告（速報）」， http://www.nilim.go.jp/lab/bbg/saigai/h28/itoigawa01.pdf, (2017. 1)

6) 系魚川市駅北大火対策本部, 「系魚川市駅北大火対応 状況 平成 29 年 1 月 10 日午後 3 時 30 分現在」, http://www.city.itoigawa.lg.jp/secure/19850/【1月 10 日午 後配布】記者発表資料.pdf, (2017.1)

7) 日本火災学会,「火災便覧」，第3 版,(1997)

8) 川越 邦雄, 「新訂建築学大系 21 建築防火論」,(1970)

9) 自治省消防研究所,「消防研究所技術資料」, 第 11 号, (1977)

10) 東京消防庁，「兵庫県南部地震に伴う市街地大火の延 焼動態調查報告書」, (1995)

11）糸魚川市大規模火災を踏まえた今後の消防のあり方 に関する検討会，「系魚川市大規模火災を踏まえた 今後の消防のあり方に関する検討会報告書」， http://www.fdma.go.jp/neuter/about/shingi_kento/h29/itoig awa_daikibokasai/06/houkokusyo.pdf, (2017)

12) 林 吉彦ほか，「大規模木造建物実大火災実験で発
生,飛散した火の粉の降積量と個別計測」，日本建築 学会技術報告集第 20 巻第 45 号, (2014)

13）長谷見 雄二ほか，「木造 3 階建て学校の実大火災実 験（予備実験）（その1〜その 14）」, 日本建築学会 大会学術講演梗概集（東海）,(2012)

14）岩見 達也, 林 吉彦, 橋本 隆司, 「木造建築物燃焼時 の火の粉飛散性状のモデル化」, 日本火災学会研究発 表会概要集, (2015)

15) 震災予防調査会, 「震災予防調査会報告 第百号 (戌)」，(1925)

16) 中央防災会議 災害教訓の継承に関する専門調査会, 「1923 関東大震災報告書 第 1 編」, (2006)

17）相馬 清二,「被服廠跡に生じた火災旋風の研究」, 地 学雑誌, Vol.84, No.4, pp.119-129,(1974)

18）篠原 雅彦, 松原 早苗, 「東日本大震災で目撃された 火災旋風」，季刊消防防災，No.108,(2012)

19) Soma, S. and Saito, K., "Reconstruction of fire whirls using scale models", Combustion and Flame, Vol. 86, pp. 269-284, (1991)

20) Dessens, J., "Man-made tornadoes", Nature, Vol.193, pp. 13-14, (1962)

21) Shinohara, M. and Matsushima, S., Formation of fire whirls: Experimental verification that a counter-rotating vortex pair is a possible origin of fire whirls, Fire Safety Journal, Vol. 54, pp. 144-153, (2012)

22) Ebert, C. H. V., "Hamburg's fire storm weather," NFPA Quarterly, Vol. 56, pp. 253-260, (1963)

23) Himoto, K. and Naruse, T., "Probabilistic aspect of fire whirl generation around an L-shaped fire source in a crosswind", Fire Safety Journal, Vol. 88, pp. 89-95, (2017)

24) Lei, J., Liu, N., Zhang, L. and Satoh, K., "Temperature, velocity and air entrainment of fire whirl plume: a comprehensive experimental investigation", Combustion and Flame, Vol. 162, pp. 745-758, (2015) 